\title{
Characteristics of the innovation activities of firms in Europe: a critical review of international differences
}

\section{Marek Vokoun ${ }^{1}$}

\begin{abstract}
A sample of 18 papers and 32 data sets revealed 210,404 firm level observations about European firms making decisions about innovation. A total of 66,965 observations describe activities of innovators between 1986 and 2008. This paper used a basic literature review to assess properties of innovation among quite rare full CDM (Crépon, Duguet, and Mairesse) papers. This study compared results from two systems of estimation and showed that both international and regional comparisons are rather problematic because of different definitions of innovation variables and data set representativeness. On average, a typical firm that engaged in innovation was a large firm competing in international markets in the sample of firms with $20+$ employees. Smaller firms, however, invested more in research and development (R\&D) and no linear relationship was found for output characteristics. Cooperation on R\&D projects increased overall innovation intensity. There is strong evidence that public funding had an ambiguous effect on R\&D spending and no additional effect on innovation output on average. This output measured by sales from innovated goods and services was on average in a positive relationship with labour productivity; however, a detailed view suggested this effect was present only in product innovation. In this paper, it is shown that results of innovation studies cannot be compared or used in research without deeper analysis of the data sample (micro companies, industries, active firms, entrants etc.), dependent variable (innovator, $R \& D$ expenditures, sales, productivity, new product, new service etc.) and the baseline company that is defined by independent variables.
\end{abstract}

Key words: Innovation, Europe, attributes, properties, decision to innovate, expenditures, value added

JEL Classification: O33, L60, D24, O38

Received: 1 June 2016 / Accepted: 30 June 2017 / Sent for Publication: 12 September 2017

\section{Introduction}

Large datasets of Community Innovation Survey (CIS) were collected. These bodies were to some extent comparable. An econometric model (CDM; Crépon et al., 1998) is

\footnotetext{
${ }^{1}$ Department of Management, Institute of Technology and Business in České Budějovice, Okružní 517/10, 370 01, Czech Republic. E-mail: marek.vokoun@mail.vstecb.cz
}

(C) 2017 by the authors; licensee Review of Economic Perspectives / Národohospodářský obzor, Masaryk University, Faculty of Economics and Administration, Brno, Czech Republic. This article is an open access article distributed under the terms and conditions of the Creative Commons Attribution 3.0 license, Attribution - Non Commercial - No Derivatives. 
used for evaluating data generated by CIS. This model imposes the casual chain assumption to fit the process definition of innovations (Greenhalgh and Rogers, 2009). Innovation processes start with a decision to innovate and end up changing the enterprises' performance. The CDM model is an approach to analysing collected CIS data and allows researchers to study and compare innovations, which are very complex phenomena on the enterprise level. CIS data sets provide enterprise level data about innovation activities, such as questions on importance of innovation factors, expenditures, or the nature of innovations. Our goal is to find a common ground or similarities of the results of various CDM studies. In total, 18 papers were collected that included 32 data sets from EU countries and Russia. From all available studies, we selected these which cover studies from countries covering the period between 1998 and 2008.

This paper follows up on Raymond et al.'s (2008) analysis of CDM models, the CDM model overview conducted by the Organisation for Economic Cooperation and Development (2009), and the analysis featured in the Mairesse and Mohnen (2010). The paper focuses on the most comparable fully realized CDM model studies from European countries, which proves its necessity. Our study is also important because it tries to demonstrate that papers on innovation can hardly be compared as already proven by literature (Hall and Rosenberg, 2010). They also provide only a limited view of innovation activities in enterprises. On one hand, an issue with dependent variable specifications exists. On the other hand, there is an issue with rather poor data sample representativeness. The innovation attributes analysis, therefore, focuses more on signs instead of on weighted average of estimated parameters, or sophisticated regression. A possible solution exists. It is an approach that allows comparison, the so-called harmonized approach for national data samples. It was featured in the 2008 study conducted by the Organization for Economic Cooperation and Development.

Innovation econometric modelling in the field of Research and Development and Innovation $(R \& D \& I)$ has been rapidly developing in the post-World War II period. Many estimation methods (Heckman, 1976; Zellner and Theil, 1962), and approaches (Solow, 1964; Van Breven, 2012) have been introduced. They test various hypotheses dealing with innovation of enterprises (Mansfield, 1963), or economic growth (Kuznets, 1955).

A discussion on the importance of research and development activities for enterprises' productivity increase started in literature on industrial organization. It triggered the never-ending debate (Schmookler, 1959) about monopoly, oligopoly, and progressiveness of small enterprises. Today's economists debate on how to definitively answer questions (Gilbert, 2006) on the Schumpeterian defence of large enterprises in dynamic environments.

\section{Literature review}

The first large sample econometric models (Mansfield 1965; Griliches 1964) were introduced in close connection to the econometric specifications of the production function in the case of the manufacturing industry (Solow 1964). This achievement comes with some issues and limitations. These are the strict assumptions regarding the linear relationship of the production function which are usually tacitly assumed by researchers and relaxed by better model specification and the control variables. These assumptions 
about perfect market conditions make the use of the standard production function models even more imprecise.

The R\&D functions were popularized in Mansfield (1965) as a mix of (1) research expenditures (as the R\&D input) and (2) number of important inventions (as the R\&D output). In his work we can encounter another important debate about R\&D literature which was further promoted by Arrow (1962). It examines some public policies promoting $\mathrm{R} \& \mathrm{D}$ projects and deals with possible underinvestment in $\mathrm{R} \& \mathrm{D}$ and basic research (David et al. 2000). Mansfield (1964) encountered several estimation issues like endogeneity bias in ordinary least square (OLS) approach. He was also concerned about the R\&D knowledge function because the data were hard to collect and analysis depended on the firms reporting truthfully its financial indicators and research expenditures.

We can also only assume our data to be credible and representative. But there are serious CIS data limitations. For example, there is discontinuity of questions, modification of questions in time, zero and missing values sometimes indistinguishable from each other, missing financial data, missing firm observations in some CIS waves, voluntariness of participation in some countries, impossibility of capturing a representative sample of firms which are entering and leaving the market.

It took about thirty years for present approaches like the original CDM model (Crépon et al. 1998) to solve complicated maximum likelihood estimates, mainly due to the limited computer computational capacity. The CDM, LH-CDM (Lööf and Heshmati 2006), and G-CDM (Griffith et al. 2006) models became popular because they gave researchers a more efficient way to estimate innovation characteristics and get the most out of Community Innovation Surveys (CIS). They became popular because they are easy to replicate, i.e. they provided an easy way to use statistical software for CIS data analysis. However, the limitations of the Cobb-Douglas linear production function and reporting problems have remained and researchers have to be careful and perhaps not too optimistic in the empirical findings of their production function models.

Of course, various CDM, LH-CDM, and G-CDM models are not estimated in the same way (see overview of methods and dependent variables in Hall and Mairesse 2006). Adjustments are primarily done because of the complicated and imperfect nature of the CIS data. The results of these different methods are not always directly comparable across authors. Identification strategy and a slightly different definition of an innovating firm changes the analysis outcomes and makes the comparison problematic. We are interested only in cross-sectional models because there is limited number of dynamic panel CDM papers to this date (for dynamic panel estimation see Raymond et al. 2015).

The CDM and LH-CDM models can be written as a recursive ${ }^{2}$ System (1) of four econometric equations:

\footnotetext{
${ }^{2}$ The causality is only assumed and it can be hardly analyzed, f.e. in terms of Granger causality, in a cross-sectional setting.
} 


$$
\begin{aligned}
& r_{i}^{*}\left\{\begin{array}{c}
1 \text { if } r_{i}=\left(X_{1 i} \beta_{1}+\varepsilon_{i_{1}}\right)>0 \\
0 \text { otherwise }\left(r_{i} \leq 0\right)
\end{array}\right. \\
& \text { I. }\left\{r _ { i } ^ { * } \left\{\text { otherwise }\left(r_{i} \leq 0\right)\right.\right.
\end{aligned}
$$

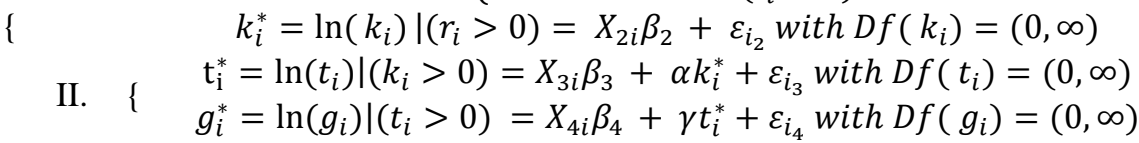

where $X n_{i} \beta_{\mathrm{n}}$ 's (with $\mathrm{n}=1,2,3$, and 4 ) are vectors of explanatory variables and $\varepsilon_{-i n}$ 's (with $\mathrm{n}=1,2,3$, and 4) are random error terms. The error terms are assumed to be independent of the exogenous variables. In the first (I.) and the second part (II.), the error term can be estimated as a system. A system of four econometric equations (1) allows for arbitrary correlations among the four disturbances. The vector of parameters to be estimated is denoted $\beta_{\mathrm{n}}$ (with $\mathrm{n}=1,2,3$, and 4 ) and the single parameters to be estimated are $\alpha$ and $\gamma$.

The first equation $\left(r_{i}^{*}\right)$ accounts for the selection into R\&D activities. We are interested in the probability of a firm $i$ to engage in continuous $\mathrm{R} \& \mathrm{D}$. This is specified as a probit model, i.e. $\mathrm{P}\left(\mathrm{r}_{\mathrm{i}}^{*}>0\right)=\Phi\left(X_{I i} \beta_{1}\right)$, where $\mathrm{r}_{\mathrm{i}}^{*}=1$ if the firm $i$ is an innovator (different definitions) and reports $R \& D$ expenditures. The second linear equation $\left(\mathrm{k}_{\mathrm{i}}^{*}\right)$ describes innovation input, which is related to the log of R\&D expenditures and the number of employees of a firm $i$, conditional of being an innovator and doing $\mathrm{R} \& \mathrm{D}$.

In both equations, there are a number of potential innovation attributes $\left(X n_{i} \beta_{\mathrm{n}}{ }^{\text {'s }}\right)$. For example, a firm's size, or size categories, the Hefindal index, ownership, being-part-ofa-group of companies, cooperation, subsidies etc. Some of them are used uniquely to identify each equation in a simultaneous estimation. The first equation uses hampering factors; the second one uses technology push and demand pull factors.

Both equations $\left(r_{i}{ }^{*}\right.$ and $\left.k_{i}^{*}\right)$ can be estimated together. The Tobit II generalized procedure is used, which controls for selection bias through a non-selection hazard variable (Mill's ratio) in the second equation (Heckman 1976).

The third linear equation $\left(\mathrm{t}_{\mathrm{i}}^{*}\right)$ models the innovation sales of goods and services log to the number of employees. We are interested in the input-output elasticity $\alpha$ and other explanatory variables $\left(\mathrm{Xn}_{i} \beta_{\mathrm{n}}{ }^{\text {'s }} \mathrm{s}\right)$ describing behaviour and market characteristics of innovators. The fourth linear equation $\left(\mathrm{g}_{\mathrm{i}}^{*}\right)$ describes labour productivity, which is related to the value added (or sales of goods and services) to the number of employees. In this equation, we have to control for endogeneity of the parameter $\gamma$.

Both equations $\left(\mathrm{t}_{\mathrm{i}}{ }^{*}\right.$ and $\mathrm{g}_{\mathrm{i}}{ }^{*}$ ) are estimated simultaneously in an instrumental variables approach. Usually, the 3-stage least square technique (3SLS; Zellner and Theil 1962) is used to instrument endogenous variables and adjust the random error terms $\varepsilon_{i 3}$ and $\varepsilon_{i 4}$. Some of the variables are used uniquely as instruments to identify each equation in a simultaneous estimation. In the third equation, market orientation variables are used and the fourth utilizes hampering factor variables (for detailed choice of explanatory variables, identification strategy, and possible attenuation bias in regressions see Andersson et al. 2012).

Usual statistical software does not report robust standard errors and marginal effects for the first equation $\left(r_{i}^{*}\right)$. As a routine, Tobit II procedure is estimated, which creates a 
non-selection hazard variable (Mill's ratio) for the classic Heckman procedure. Then probit $\left(\mathrm{r}_{\mathrm{i}}{ }^{*}\right)$ with marginal effects coefficients and robust standard error and OLS with robust standard error and Mill's ratio variable can be estimated separately. The 3SLS is recommended to bootstrap 50 times (Efron 1979) or use the jackknife procedure (Gould 1995) to account for possible bias in OLS estimation.

Another approach is a G-CDM model which is preferred in recent studies. The G-CDM model can be written as a recursive System (2) of five econometric equations:

$$
\begin{aligned}
& r_{i}^{*}\left\{\begin{array}{c}
1 \text { if } r_{i}=\left(X_{1 i} \beta_{1}+\varepsilon_{i_{1}}\right)>0 \\
0 \text { otherwise }\left(r_{i} \leq 0\right)
\end{array}\right. \\
& \text { I. }\left\{r _ { i } ^ { * } \left\{0 \text { otherwise }\left(r_{i} \leq 0\right)\right.\right. \\
& k_{i}^{*}=\ln \left(k_{i}\right) \mid\left(r_{i}>0\right)=X_{2 i} \beta_{2}+\varepsilon_{i_{2}} \text { with } D f\left(k_{i}\right)=(0, \infty) \\
& \operatorname{prod}_{i}^{*}\left\{\begin{array}{c}
1 \text { if product } \\
\text { 0 otherwise }\left(\text { product }_{i} \leq 0\right)
\end{array}\right. \\
& \text { II. }\left\{\operatorname { p r o c } _ { i } ^ { * } \left\{\begin{array}{c}
1 \text { if } \text { process }_{i}=\left(\sigma k_{i}^{*}+X_{4 i} \beta_{4}+\varepsilon_{i_{4}}\right)>0 \\
0 \text { otherwise }\left(\text { process }_{i} \leq 0\right)
\end{array}\right.\right. \\
& g_{i}^{*}=\ln \left(g_{i}\right)=X_{5 i} \beta_{5}+\pi \operatorname{prod}_{i}^{*}+\varphi \operatorname{proc}_{i}^{*}+\varepsilon_{i_{5}} \text { with } D f\left(g_{i}\right) \\
& =(0, \infty)
\end{aligned}
$$

where the first part (I.) in the System (2) is the same as in the System (1), but the second part differs substantially. Innovation output $\left(\operatorname{prod}_{i}{ }^{*}\right.$ and $\left.\operatorname{proc}_{i}{ }^{*}\right)$ is described as a bivariate knowledge production function. It models the probability that a firm has introduced a product (or a process) innovation over the last three years. The endogenous variable is innovation input $\left(\mathrm{k}_{\mathrm{i}}^{*}\right)$ and there are two parameters, $\rho$ and $\sigma$, to be estimated. This bivariate model assumes a correlation between those parameters ( $\rho$ and $\sigma)$ and the error term (Mairesse and Mohen 2002).

The fifth equation is the same with the exception of innovation. There are two endogenous dummy variables $\left(\operatorname{prod}_{i}{ }^{*}\right.$ and $\left.\operatorname{proc}_{i}{ }^{*}\right)$ with parameters $\pi$ and $\phi$ to be estimated. The second part (II.) can be better estimated in the two stage procedure (Andersson et al. 2012) using predicted values of $\left(\mathrm{k}_{\mathrm{i}}{ }^{*}\right)$ in the bivariate probit equations in the first step. In the second step, we estimate maximum likelihood of the three equation model.

Some of the authors (Appendix, Table 1) split their samples and introduced manufacturing and service sectors separately. This is done because these sectors are different from each other (Ettlie and Rosenthal 2011) and the authors decided that more than a dummy variable was needed to control for the type of industry.

Recently, new CDM papers were published as well (see summary in Vokoun 2016), but they use the data from the period of the economic crisis (years 2008-2010). In this paper, the period of crisis is omitted. The survival rates of companies in the economic crisis depend on many economic factors (Vochozka et al. 2015) which influence innovation policies and strategies of firms. Further research should be aimed at differences in the results from the pre-crisis and crisis period.

Both Systems are useful for innovation process analysis and none of them outperforms the other one. It simply depends on the way the variables are defined and the results interpreted. System 1 allows an analysis of innovation output in terms of financial interpretation. System 2 is more in accordance with the economic theory and original CDM 
model which includes patents as dependent variable in the third equation. The interpretation of coefficients of well-defined type of innovation at the firm level is clearer and more comprehensible than the guessed shares of sales from innovated goods and services made by a firm employee.

The choice of the estimation procedure depends also on data availability because not all data samples can be merged with financial data, which makes the System 2 approach preferable at least for the partial innovation process analysis. Both Systems are easy to be replicated which makes them very important for economic analysis. New approaches using data envelopment analysis and other non-parametric approaches to production analysis are too complex and require detailed financial data.

\section{Methodology}

The goal of this study was to introduce a meta-analysis. However, in the process of data collection, there were too many factors making meta-analysis impossible. There are substantial limitations of the CIS datasets which make comparison in time and space very problematic (see Literature review). There are other limitations as well, for example, at least two estimation methods (System 1 and System 2, see Literature review) and also differences between the definitions of dependent variables, and also their per employee normalization (compare Hashi and Stojčić 2013; Masso and Vahter 2008). There are studies dealing with manufacturing industry only, some papers deal exclusively with medium and large companies, and only a fraction includes micro and small firms. This makes standard meta-analysis problematic and collected beta coefficients, standard errors and p-values can be analyzed only in a simple meta-analysis procedure which resembles more of a critical review than a full meta-analysis or regression coefficients.

The selection of papers is based on the inclusion in Web of Science (WOS) database and some peer reviewed papers were discovered also by using the Google Scholar search engine (GSSE). The phrase "Community Innovation Survey" was used to analyze topics (title, keywords, and abstract) of papers in WOS database. Papers with all stages of the CDM model were then selected, papers focusing exclusively f.e. on the first stage of innovation process were not included. Then the phrase CDM and Innovation was used to search for other papers in the WOS database. Some articles have been discovered in the reference lists of the analyzed literature. In this study, there is a publication bias in the form of overlapping data samples and three analyzes are not published in a respected journal. The analysis of Polder et al. (2009) and Roud (2007) were reviewed at the conference and the analyzes of Roud (2007) and Damijan et al. (2011) were published in books. There is no doubt that those authors are capable of the CIS data analysis because of their cooperation with other respected authors and in the EU Framework Programmes in the field of innovation economics.

The actual comparison and process of finding similarities is based on the mathematical sign of statistically significant regression coefficient at the $5 \%$ level (type I. error). The interpretation of the share of the observed signs is individual, because there are too many factors which would make simple meta-analysis biased. The analysis is aimed at cross-sectional data and independent variables are referred in literature and as determinants of innovation activity (causality is assumed), but in this paper we use rather the neutral term attributes of innovation (or properties, dimensions). 


\section{Results}

The size of a firm, measured by the number of employees, increases the probability to engage in an innovation project (Appendix Table 2). Only two papers in our sample did not report statistically significant relationship (Doran and O'Leary 2011; Classen et al. 2014). However, most of the time, companies with 20 or less employees and, in some cases, even 50 or less employees are not observed. These smaller companies are considered a dynamic market component. Their survival rate is lower and we don't know much about them from the CIS surveys. Thus, we observe a rather static group of relatively stable medium and large companies. The size of the company can be co-defined also by the turnover; however, no paper in the sample used it.

We can also face a problem with over-reported R\&D because of tax incentives and other R\&D benefit programs. Then, there is a possible crowding out effect of public subsidies. Will firms, and if so which, do their R\&D projects anyway? Lokshin and Mohnen (2010) looked at this issue and assessed level-based R\&D incentives in the Netherlands which are aimed at tax incentives from all qualified R\&D expenditures and found higher crowding out probability for larger companies.

To control for the market dynamics, a small fraction of the studies presented industrial organization (IO) variables like entrant variable, mergers and acquisitions indicators, being part of a group of companies, the Herfindahl index (HHI), and market share indicators (CR3, CR4). International competition as a propensity indicator of the market orientation variable was an important indicator (Appendix, Table 3). Firms engaged more in an innovation project if they were focusing on more distant markets like the US and China, for example. In the detailed view, the EU market orientation was not statistically significant in two cases (Janz et al. 2004; Ebersberger and Lööf 2005).

There are only a few CDM models (Griffith et al. 2006; Masso and Vahter 2008) that deal with appropriability conditions (Levin et al. 1987; Cohen et al. 2000). They can be divided into two approaches: (1) the use of formal protection and (2) the use of strategic protection. The formal protection, i.e. the use of trademarks, copyrights and other legal methods, is used by firms to protect their inventions. The use of the marketing mix with secrecy and lead time advantage on competitors belongs to strategic behavior. We observe a positive relationship with appropriability conditions in Griffith et al. (2006) and Masso and Vahter (2008) papers. These two approaches, or a mix, allow companies to get returns from innovative activities.

The decision to innovate is controlled for industry and time dummy variables and hampering factor variables. Public support and incentives to engage in R\&D are not usually estimated because a $R \& D$ subsidy means future $R \& D$ expenditures and a positive coefficient is assumed (Masso and Vahter 2008). However, we are more interested in the effectiveness of public subsidies in terms of higher innovative output (number of patents and amount of sales from innovated goods and services).

This first equation splits the sample into 2 groups. We do not know how much the firms spent on R\&D projects two years ago, or how much they really appropriated (were able to get returns from innovated goods and services) from them. The quality of innovators is defined by the declaration of an innovator. As mentioned before, this is usually a firm 
that introduced a new-to-the-market innovation and had positive sales from the innovated good or service.

A dependent variable in the second equation is the amount of $R \& D$ expenditures per employee. There is more than one definition of $R \& D$ expenditures. In most papers, authors used the CIS definition, i.e. there is a positive value across all basic expenditures related to innovation activities: R\&D based goods and service innovation, purchases of goods and capital for innovation activities, preparation of innovation activities, education, and marketing expenditures.

However, researchers usually cut the sample for practical reasons and include only firms with positive innovation output (a product or process innovation, patent application, or sales from innovated goods and services) and omit the firm with positive R\&D and zero innovation output. A Mill's ratio in cross-section analysis might, to some extent, control for this selectivity bias. There are more biases likely to arise. Crépon et al. (1998, p. 36) found different estimates of size using OLS and ML in the second equation, but reported the more efficient ML estimates as the final results.

The firm's size also depends on the industry's usual amount of tangible capital and labor intensity. Some industries are more labor intensive and, in absolute values, the largest R\&D spenders. However, there is strong evidence that size has, on average, a negative impact on R\&D intensity and that there are decreasing marginal returns from labor (Appendix, Table 4). In the analyzed data sample, there are about 9 cases suggesting negative relationship, 4 cases suggesting no relationship (Crépon et al. 1998; Janz et al. 2004; Ebersberger and Lööf 2005), one case suggesting nonlinear relationship (Vokoun 2016), and one suggesting positive relationship (Damijan et al. 2011).

Cooperation is a statistically significant and positive attribute of $R \& D$ per employee expenditures, and in two cases (Raffo et al. 2008; Griffith et al. 2006) it was statistically insignificant (Appendix, Table 5). The international competition is measured as the propensity to operate on more distant markets (EU and world market orientation). We observe both positive and zero influence of the firm's foreign market orientation.

Detailed subsidies division sheds more light on how efficient the EU subsidies are (Appendix, Table 6). Again, it is very probable that a firm engaging in innovation activity supported by public funding would spend more on R\&D per employee on average, however, there are some doubts about it. Local funding seemed to have zero effect, and there are ambiguous results at the national level. There is room for rent-seeking and sometimes public funds are spent differently than private funds and reserves.

Again, only few of the papers reported market variables like HHI, CR3, and other important variables like foreign ownership, appropriability conditions and total exports. Control variables were usually demand pull, technology push, sources of information, and industry dummies.

There is no evidence for a strong linear relationship between innovation output and firm's size. In the detailed view (Appendix, Table 7 and Table 8), it seems again that size does not have an effect at all, but medium-to-large firms with 250-999 employees perform better in innovation output than others. 
Cooperation seems to be an important factor for innovation output (Appendix, Table 9). Firms engaging in a mutual R\&D project will most likely benefit on average from higher innovation sales, but, for some reason, not in the Denmark and Swedish manufacturing industry. One observation of the Herfindahl index is a negative one (Castellacci 2011). There is, on average, a negative relationship between concentration and innovation output. An interesting control variable would be HHI in square form as used in Vokoun (2016). Results suggest a non-linear relationship and different effects in time.

Public support seems again complicated and a detailed (Appendix, Table 10) view is needed. Most results are negatively significant or not significant at all. Two cases are positive - Sweden and product innovation in Estonia. On average, public funding seems to have no effect on the firm's innovation output.

The elasticity of innovation output with respect to R\&D expenditures per employee (innovation input) varied a lot (Appendix, Table 11). Results ranged from Russian 0.267 to Swedish 0.614 (System 1 estimates) and Estonian 0.107 to Dutch 1.044 (System 2 estimates), and many results were not significant at all. There appear to be country differences that correlate to some extent with the patent output and the level of GDP per capita, but this issue has to be further tested.

Productivity had an ambiguous impact on innovation in the System 1 approach. A positive effect was expected but some of the results were statistically not significant (Appendix, Table 12). There exists a possible influence of time and the existence of innovation cycles should be further researched.

The capital intensity (log of tangibles per employee) effect ranged from zero in Sweden to 0.360 in the Netherlands (Appendix, Table 13 and Table 14). There seem to be country differences and the results might also depend on the choice of control variables. Some of the papers included highly skilled workers (graduates, engineers), total export, international competition, demand pull, and hampering factor variables. Innovation sales had mostly a positive effect on productivity and we also observed insignificant results. Coefficients ran from Swedish 0.012 to Norwegian 0.476. Hashi and Stojcic (2013) reported that elasticity was 1.638, but a different CDM approach was used. There are mostly statistically insignificant results (System 2) regarding the process innovation. Significant results with high values were observed only for the Dutch service sector, and in Estonia in the 2004 CIS wave.

Both the physical capital and the innovation output increased the productivity of a firm in terms of the sales per employee (or turnover per employee), however, there are some doubts when using the more detailed and efficient estimation (System 2). Process innovation seemed to have an effect only in the service sector and in a small developing country. The product innovation was beneficial only in one-half of the observations.

The estimated coefficient of the firm's size effect in productivity varies a lot (Appendix, Table 15). The size coefficient takes on values around zero. In Germany and Denmark the coefficient is quite high, positive and the returns to scale are larger than one. In Russia, Norway, and Slovenia, there is a negative marginal return from an additional labor unit.

As before, there is a lot of variation in the coefficients. On average, we can observe a positive coefficient for larger companies with 1000 and more employees (Appendix, 
Table 16). It seems that a non-linear relationship is possible. A few papers included skilled labor showing a positive boost on productivity and the coefficient for capital intensity which takes on values from 0.05 (Swedish services) to 0.36 (Denmark) was present.

\section{Conclusion}

Cross-country studies examining the relationship between innovation and productivity usually use aggregated data. The CDM studies and microeconomic studies are still quite rare. Firms are reporting their activities on a regular basis and more and more data can be analyzed. There are useful frameworks (Mairesse and Mohen 2002; Mairesse and Mohnen 2010) which allow us to study the Community Innovation Survey datasets in detail.

This paper aimed the CDM papers that analyzed innovation as a process. A sample of 18 papers and 32 data sets contained 210,404 units deciding about innovation. The analyzed sample does not consist of unique firms, and the number of unique firms is lower. A total of 66,965 firms had innovated their goods and services over the period of 19862008. This paper used a basic critical review, a very basic meta-analysis approach, because full CDM studies are still quite rare. Another issue was the differences in estimation procedures (System 1 and System 2, see method) and dependent variable identification.

We were able to shed some light on innovation attributes in an international and regional context. The size of the firm seems to be an important factor in the statistical population of companies with 20 and more employees. A typical innovator in this population is a large firm that competes in international markets. However, there is strong evidence that larger firms spent, on average, less on R\&D activities than smaller firms. The problem of analyzed papers is that micro and small companies are omitted and the Schumpeterian debate is still unresolved.

There seems to be no linear relationship between firm size and innovation output or labor productivity. In a structured view, we observed medium-to-large firms (250-999 employees) having a positive impact on innovation input (introduction of a product and process innovation) and large firms (1000+ employees) to be more productive than the smaller ones (20-49 employees). But again, there are serious doubts regarding production function results because of the omission of entrant firms and micro companies ( 9 and less employees).

Cooperation appeared to be a positive property of the R\&D spending and innovation output in the sample of companies with $20+$ employees. There is strong evidence that public support is not an efficient public policy. Firms would have invested more with public funding than without it. However, ambiguous results were observed in the detailed view. Public funding had no effect at the local government level. There was sometimes even a negative and statistically significant effect on the national level. Another strong evidence of public funding inefficiency was found when dealing with innovation output.

$R \& D$ expenditures were a positive property of innovation output (20+ employees) and varied a lot. Productivity had no clear-cut effect on innovation output, but overall it was 
a non-negative innovation output attribute. The other way round, innovation output, in terms of sales of innovated goods and services, was a positive attribute of labor productivity, but in the detailed view there are some doubts, as well. It seems that only product innovations had this positive effect.

There are still no definite answers, but the phase in which a factor is affecting innovation must be distinguished. This study explored the interesting historical period of 19862008 which was characterized by massive technological and social changes. This paper proposes a more detailed fashion of results interpretation which utilizes newest versions of CDM econometric modelling in the field which are advancing the approaches described by System 1 and System 2 estimation methods. There are some unanswered questions concerning market dynamics and the underpinnings of the innovation process at the firm level. They prevail simply by comparing studies which are not directly comparable. Further research is still needed to bring new perspectives.

For example, there is a case of the Schumpeterian effect. Schumpeter and his followers (Schumpeter 1934; Villard 1958; Schmookler 1959) suggest the existence of the creative destruction process and potential competitors. This means that data samples with omitted category of firms with 9 and less employees cannot capture the effects of competing entrants and cannot give a definite and comparable results to the debate about Schumpeterian effect. For Schumpeter and its followers, the innovation analysis cover all kind of innovations including organizational, product and process innovation. But for many authors analyzed in this paper the innovation analysis covers only significant innovation activities which are risker and new to the market. In other words, dependent and independent variables differ substantially, the baseline companies in regressions as well, and data representativeness is generally very poor and only a fraction of authors criticize the CIS data credibility.

Funding: This work was supported by the Department of Management at the Institute of Technology and Business in České Budějovice.

Disclosure statement: No potential conflict of interest was reported by the author.

\section{References}

ANDERSSON, M., JOHANSSON, B., KARLSSON, C. \& LÖÖF, H. (2012). Innovation and Growth: From R\&D Strategies of Innovating Firms to Economy-wide Technological Change. Oxford: Oxford University Press.

ARROW, K. (1962). Economic Welfare and the Allocation of Resources for Invention. In: R. R. Nelson (ed.). The Rate and Direction of Inventive Activity: Economic and Social Factors. Princeton: Princeton University Press, pp. 609-626.

BAREGHEH, A., ROWLEY, J. \& SAMBROOK, S. (2009). Towards a multidisciplinary definition of innovation. Management Decision. 47 (8). pp.1323-1339. DOI: http://doi.org/10.1108/00251740910984578

BROZEN, Y. (1951). Invention, Innovation, and Imitation. The American Economic Review, 41(2), 239-257. 
CASTELLACCI, F. (2011). How does competition affect the relationship between innovation and productivity? Estimation of a CDM model for Norway.Economics of Innovation and New Technology, 20(7), 637-658.

CLASSEN, N., CARREE, M., Van GILS, A., \& PETERS, B. (2014). Innovation in family and non-family SMEs: an exploratory analysis. Small Business Economics, 42 (3), pp. 595-609. http://doi.org/10.1007/s11187-013-9490-z

COHEN, W.M., NELSON, R.R. \& WALSH, J.P. (2000). Protecting Their Intellectual Assets: Appropriability Conditions and Why U.S. Manufacturing Firms Patent (or Not). [Online]. National Bureau of Economic Research. Available from: http://www.nber.org/papers/w7552. [Accessed: 9 July 2012].

CRÉPON, B., DUGUET, E., \& MAIRESSEC, J. (1998). Research, Innovation And Productivi [Ty: An Econometric Analysis At The Firm Level. Economics of Innovation and new Technology, 7(2), 115-158.

DAMIJAN, J. P., KOSTEVC, Č., \& ROJEC, M. (2011). Innovation and firms' productivity growth in Slovenia: Sensitivity of results to sectoral heterogeneity and to estimation method (pp. 165-193). Berlin: Springer Berlin Heidelberg.

DAVID, P.A., HALL, B.H. \& TOOLE, A.A. (2000). Is public R\&D a complement or substitute for private R\&D? A review of the econometric evidence. Research Policy. 29 (4-5). pp.497-529. http://doi.org/10.1016/S0048-7333(99)00087-6

DORAN, J., \& O'LEARY, E. (2011). External interaction, innovation and productivity: an application of the innovation value chain to Ireland. Spatial Economic Analysis, 6 (2), pp. 199-222. http://doi.org/10.1080/17421772.2011.557777

EBERSBERGER, B. \& Lööf, H. (2005). Innovation Behaviour and Productivity Performance in the Nordic Region Does Foreign Ownership Matter? [Online]. Royal Institute of Technology, CESIS - Centre of Excellence for Science and Innovation Studies. Available from: http://econpapers.repec.org/paper/hhscesisp/0027.htm. [Accessed: 27 March 2012].

EFRON, B. (1979). Bootstrap Methods: Another Look at the Jackknife. The Annals of Statistics. 7 (1). pp.1-26. http://doi.org/10.1214/aos/1176344552

ETTLIE, J.E. \& ROSENTHAL, S.R. (2011). Service versus Manufacturing Innovation. Journal of Product Innovation Management. 28 (2). pp.285-299. http://doi.org/10.1111/j.1540-5885.2011.00797.x

FASSIO, C. (2015). How Similar is Innovation in German, Italian and Spanish Medium-Technology Sectors? Implications for the Sectoral Systems of Innovation and Distance-to-the-Frontier Perspectives. Industry and Innovation, 22 (2), pp. 102-125. http://doi.org/10.1080/13662716.2015.1033160

GILBERT, R.J. (2006). Looking for Mr. Schumpeter: Where Are We in the Competition--Innovation Debate? Innovation Policy and the Economy. 6. pp.159-215.

GOULD, W. (1995). Jackknife estimation. Stata Technical Bulletin. 4 (24). pp.25-29.

GREENHALGH, C. \& ROGERS, M. (2009). Innovation, Intellectual Property, and Economic Growth. Princeton University Press. 
GRIFFITH, R., HUERGO, E., MAIRESSE, J., \& PETERS, B. (2006). Innovation and productivity across four European countries. Oxford review of economic policy, 22 (4), 483-498. http://doi.org/10.1093/oxrep/grj028

GRILICHES, Z. (1964). Research Expenditures, Education, and the Aggregate Agricultural Production Function. The American Economic Review. 54 (6). pp.961-974.

HALL, B. H., LOTTI, F., \& MAIRESSE, J. (2009). Innovation and productivity in SMEs: empirical evidence for Italy. Small Business Economics, 33 (1), pp. 13-33. http://doi.org/10.1007/s11187-009-9184-8

HALL, B.H. \& MAIRESSE, J. (2006). Empirical Studies of Innovation in the Knowledge Driven Economy. Economics of Innovation and New Technology 15 (4/5), 289299. http://doi.org/10.1080/10438590500512760

HALL, B.H. \& Rosenberg, N. (2010). Handbook of the Economics of Innovation Set. Berkeley: Elsevier Science.

HALPERN, L., \& MURAKÖZY, B. (2012). Innovation, productivity and exports: the case of Hungary. Economics of Innovation and New Technology, 21 (2), 151-173. http://doi.org/10.1080/10438599.2011.561995

HASHI, I., \& STOJČIĆ, N. (2013). The impact of innovation activities on firm performance using a multi-stage model: Evidence from the Community Innovation Survey 4. Research Policy, 42(2), 353-366. http://doi.org/10.1016/j.respol.2012.09.011

HECKMAN, J.J. (1976). The Common Structure of Statistical Models of Truncation, Sample Selection and Limited Dependent Variables and a Simple Estimator for Such Models. Annals of Economic and Social Measurement. 5 (4). pp.475-492.

JANZ, N., LÖÖF, H. \& PETERS, B. (2004). Firm Level Innovation and Productivity Is There a Common Story Across Countries? Problems and Perspectives in Management. Vol. 2. pp.184-204.

KUZNETS, S. (1955). Economic Growth and Income Inequality. The American Economic Review. 45 (1). pp.1-28.

LEVIN, R.C., KLEVORICK, A.K., NELSON, R.R., WINTER, S.G., GILBERT, R. \& GRILICHES, Z. (1987). Appropriating the Returns from Industrial Research and Development. Brookings Papers on Economic Activity. 1987 (3). pp.783-831. http://doi.org/10.2307/2534454

LOKSHIN, B. \& MOHNEN, P. (2010). How effective are level-based R\&D tax credits? Evidence from the Netherlands. [Online]. United Nations University, Maastricht Economic and social Research and training centre on Innovation and Technology. Available from: http://ideas.repec.org/p/dgr/unumer/2010040.html. [Accessed: 5 April 2012].

LÖÖF, H. \& Heshmati, A. (2006). On the relationship between innovation and performance: A sensitivity analysis. Economics of Innovation and New Technology. 15 (4-5). pp.317-344. http://doi.org/10.1080/10438590500512810

MAIRESSE, J. \& MOHNEN, P. (2002). Accounting for Innovation and Measuring Innovativeness: An Illustrative Framework and an Application. The American Economic Review. 92 (2). pp.226-230. http://doi.org/10.1257/000282802320189302 
MAIRESSE, J. \& MOHNEN, P. (2010). Chapter 26 - Using Innovation Surveys for Econometric Analysis. In: B. H. H. and N. ROSENBERG (ed.). Handbook of the Economics of Innovation. Handbook of the Economics of Innovation, Volume 2. [Online]. North-Holland, pp. 1129-1155. Available from: http://www.sciencedirect.com/science/article/pii/S0169721810020101. [Accessed: 1 June 2016].

MANSFIELD, E. (1964). Industrial Research and Development Expenditures: Determinants, Prospects, and Relation to Size of Firm and Inventive Output. The Journal of Political Economy. 72 (4). pp.319-340.

MANSFIELD, E. (1965). Rates of Return from Industrial Research and Development. The American Economic Review. 55 (1/2). pp.310-322.

MANSFIELD, E. (1963). Size of Firm, Market Structure, and Innovation. The Journal of Political Economy. 71 (6). pp.556-576. http://doi.org/10.1086/258815

MASSO, J. \& VAHTER, P. (2008). Technological innovation and productivity in latetransition Estonia: econometric evidence from innovation surveys. The European Journal of Development Research. $20 \quad$ (2). pp.240-261. http://doi.org/10.1080/09578810802060751

Organisation for Economic Cooperation and Development. (2005). Oslo Manual. [Online]. Paris: Organisation for Economic Cooperation and Development. Retrieved from http://www.oecdilibrary.org/content/book/9789264013100-en. [Accessed: 26 March 2016]

Organisation for Economic Cooperation and Development. (2009). Innovation in Firms: A Microeconomic Perspective. [Online]. Paris: OECD Publishing. Retrieved from http://www.oecd-ilibrary.org/science-and-technology/innovation-infirms_9789264056213-en. [Accessed: 26 March 2017]

POLDER, M., LEEUWEN, G. van, MOHNEN, P. \& RAYMOND, W. (2009). Productivity effects of innovation modes. [Online]. University Library of Munich, Germany. Available from: http://ideas.repec.org/p/pra/mprapa/18893.html. [Accessed: 26 March 2016].

RAFFO, J., LHUILLERY, S., \& MIOTTI, L. (2008). Northern and southern innovativity: a comparison across European and Latin American countries. The European Journal of Development Research,20 (2), pp. 219-239. http://doi.org/10.1080/09578810802060777

RAYMOND, W., MAIRESSE, J., MOHNEN, P., \& PALM, F. (2015). Dynamic models of R \& D, innovation and productivity: Panel data evidence for Dutch and French manufacturing. European Economic Review, 78, pp. 285-306. http://doi.org/10.1016/j.euroecorev.2015.06.002

RAYMOND, W., MOHNEN, P., PALM, F., \& van der LOEFF, S. S. (2006). A classification of Dutch manufacturing based on a model of innovation. De Economist, 154 (1), pp. 85-105. http://doi.org/10.1007/s10645-006-0005-Z 
ROUD, V., (2007). Firm-level research on innovation and productivity: Russian experience. In: Proceeding from the Conference on Micro Evidence on Innovation in Developing Countries (MEIDE). Maastricht. Available from: [Accessed: 4 March 2016].

SCHMOOKLER, J. (1959). Bigness, Fewness, and Research. Journal of Political Economy. 67 (6). pp.628-632. http://doi.org/10.1086/258251

SCHUMPETER, J. (1934). The theory of economic development: an inquiry into profits, capital, credit, interest, and the business cycle. New Jersey: Transaction Publishers.

SOLOW, R. (1964). Capital, Labor, and Income in Manufacturing. In: The Behavior Of Income Shares: Selected Theoretical and Empirical Issues. Studies in income and wealth. [Online]. Princeton: Princeton University Press, pp. 101-142. Available from: http://www.nber.org/chapters/c1844. [Accessed: 29 March 2016].

Van BEVEREN, I. (2012). Total Factor Productivity Estimation: A Practical Review. Journal of Economic Surveys. 26 (1). pp.98-128. http://doi.org/10.1111/j.14676419.2010.00631.x

VILLARD, H. H., (1958). Competition, Oligopoly, and Research. Journal of Political Economy, 66(6), 483-497. http://doi.org/10.1086/258101

VOCHOZKA, M., STRAKOVÁ, J., \& VÁCHAL, J., (2015). Model to Predict Survival of Transportation and Shipping Companies. Naše more. 62 (SI). pp.109-113.

VOKOUN, M., (2014). R\&D and Innovation Activities, Search for Better Definitions and an Economic-Historical Approach. In Proceedings of Economics and Finance Conferences (No. 0402131). International Institute of Social and Economic Sciences.

VOKOUN, M., (2016). Innovation behaviour of firms in a small open economy: the case of the Czech manufacturing industry. Empirica. 43 (1). pp.111-139. http://doi.org/10.1007/s10663-015-9296-0

ZELLNER, A., \& THEIL, H., (1962). Three-Stage Least Squares: Simultaneous Estimation of Simultaneous Equations. Econometrica. 30 (1). pp.54-78. http://doi.org/10.2307/1911287 


\section{Appendix}

Table 1 Overview of selected CDM Papers

\begin{tabular}{|c|c|c|c|c|c|c|}
\hline Author & Abbr. & Country & Waves & $\begin{array}{c}\text { Decision } \\
\text { Sample }\end{array}$ & $\begin{array}{c}\text { R\&D } \\
\text { Sample }\end{array}$ & Estimation \\
\hline Crépon et al. (1998) & CDM & France & $\begin{array}{l}1988, \\
1990\end{array}$ & 6145 & 4164 & ALS \\
\hline Vokoun (2016) & VOK & Czech Rep. & $\begin{array}{l}2001- \\
2008\end{array}$ & 7626 & 2963 & Panel S1 \\
\hline Raffo et al. (2008) & RAF F & France & 2000 & 7166 & 4618 & System 2 \\
\hline Raffo et al. (2008) & RAF E & Spain & 2004 & 4817 & 3559 & System 2 \\
\hline Raffo et al. (2008) & RAF S & Switzerland & 2001 & 1344 & 925 & System 2 \\
\hline Doran and O'Leary (2011) & $\mathrm{D} \& \mathrm{O} \mathrm{NM}$ & Ireland & 2006 & 1974 & 266 & System 1 \\
\hline Hall et al. (2009) & HALL & Italy & $\begin{array}{l}1998- \\
2004\end{array}$ & 9674 & 4015 & Panel S2 \\
\hline Fassio (2015) & FAS G & Germany & 2004 & 775 & 526 & System 2 \\
\hline Fassio (2015) & FAS I & Italy & 2004 & 3315 & 1852 & System 2 \\
\hline Fassio (2015) & FAS S & Spain & 2004 & 3526 & 2126 & System 2 \\
\hline Classen et al. (2014) & CLA & Germany & 2006 & 2087 & 1067 & System 2 \\
\hline Hashi and Stojcic (2013) & $\mathrm{H} \& \mathrm{~S}$ & 16 EU states & 2004 & 85777 & 15644 & System 1 \\
\hline Griffith et al. (2006) & GRI F & France & 2000 & 3625 & 1270 & System 2 \\
\hline Griffith et al. (2006) & GRI G & Germany & 2000 & 1123 & 442 & System 2 \\
\hline Griffith et al. (2006) & GRI S & Spain & 2000 & 3588 & 750 & System 2 \\
\hline Griffith et al. (2006) & GRI U & UK & 2000 & 1904 & 509 & System 2 \\
\hline Masso and Vahter (2008) & $\mathrm{M} \& \mathrm{~V} \mathrm{I}$ & Estonia & 2000 & 1321 & 369 & System 2 \\
\hline Masso and Vahter (2008) & M\&V II & Estonia & 2004 & 953 & 406 & System 2 \\
\hline Polder et al. (2009) & POL M & $\begin{array}{l}\text { Netherland } \\
\text { Manufact. }\end{array}$ & $\begin{array}{l}2004 \\
2006\end{array}$ & 8536 & 2578 & System 2 \\
\hline Polder et al. (2009) & POL S & $\begin{array}{l}\text { Netherland } \\
\text { Services }\end{array}$ & $\begin{array}{l}2004 \\
2006\end{array}$ & 18375 & 1676 & System 2 \\
\hline Loof and Heshmati (2006) & L\&H S & $\begin{array}{l}\text { Sweden } \\
\text { Services }\end{array}$ & 1998 & 1974 & 903 & System 1 \\
\hline Loof and Heshmati (2006) & L\&H M & $\begin{array}{l}\text { Sweden } \\
\text { Manufact. }\end{array}$ & 1998 & 1081 & 363 & System 1 \\
\hline Castellacci, F. (2011) & CAS & Norway & $\begin{array}{l}2000- \\
2006\end{array}$ & 12954 & 3570 & Panel S1 \\
\hline Janz et al. (2004) & JNZ G & Germany & 2000 & 575 & 352 & System 1 \\
\hline Janz et al. (2004) & JNZ S & Sweden & 2000 & 474 & 206 & System 1 \\
\hline Roud, V. (2007) & ROU & Russia & 2005 & 3408 & 497 & System 1 \\
\hline Ebersberger and Lööf (2005) & E\&L D & Denmark & 2000 & 844 & 429 & System 1 \\
\hline Ebersberger and Lööf (2005) & E\&L F & Finland & 2000 & 818 & 516 & System 1 \\
\hline Ebersberger and Lööf (2005) & E\&L N & Norway & 2000 & 2327 & 1119 & System 1 \\
\hline Ebersberger and Lööf (2005) & E\&L S & Sweden & 2000 & 1197 & 694 & System 1 \\
\hline Halpern and Muraközy (2012) & HAL & Hungary & $\begin{array}{l}2004 \\
2006\end{array}$ & 6154 & 3644 & System 2 \\
\hline Damijan et al. (2011) & DAM & Slovenia & $\begin{array}{l}1998, \\
2002\end{array}$ & 4947 & 4947 & System 2 \\
\hline 18 papers & 32 sets & 13/16 EU & 1988-2008 & 210404 & 66965 & $\begin{array}{l}14 \text { System } 1 \\
18 \text { System } 2\end{array}$ \\
\hline
\end{tabular}

Source: Selected CDM studies, see reference list 
Table 2 Decision to innovate - size of the firm

\begin{tabular}{|c|c|c|c|c|}
\hline Firm's size & $50-99$ & $100-249$ & $250-999$ & $1000+$ \\
\hline GRI F & $0.105 * * *$ & $0.175 * * *$ & $0.356 * * *$ & $0.429 * * *$ \\
\hline GRI G & 0.056 & $0.160 * * *$ & $0.389 * * *$ & $0.330 * * *$ \\
\hline GRI S & $0.101 * * *$ & $0.237 * * *$ & $0.418 * * *$ & $0.683 * * *$ \\
\hline GRI U & $0.110 * * *$ & $0.122 * * *$ & $0.246 * * *$ & $0.346 * * *$ \\
\hline HAL & 0.11 & $0.038 * * *$ & $0.093 * * *$ & $0.062 * * *$ \\
\hline VOK & $0.41 * * *$ & $0.77 * * *$ & $1.4 * * *$ & $1.43 * * *$ \\
\hline Firm's size & $50-99$ & $100-249$ & $250-499$ & $500+$ \\
\hline RAF F & $0.126 * * *$ & $0.216 * * *$ & $0.363 * * *$ & $0.451 * * *$ \\
\hline RAF E & $0.105 * * *$ & $0.139 * * *$ & $0.076^{* *}$ & $0.158 * * *$ \\
\hline RAF S & $0.096 * * *$ & $0.164 * * *$ & $0.212 * * *$ & $0,300 * * *$ \\
\hline Firm's size & $21-50$ & $51-250$ & & \\
\hline HALL & $0.147 * * *$ & $0.482 * * *$ & & \\
\hline \multicolumn{5}{|c|}{ Log of employees } \\
\hline CAS & JNZ G & JNZ S & CDM & $\mathrm{H} \& \mathrm{~S}$ \\
\hline $0.357 * * *$ & $0.230 * * *$ & $0.157 * * *$ & $0.268 * * *$ & $0.074 * * *$ \\
\hline $\mathrm{M} \& \mathrm{~V} \mathrm{I}$ & M\&V II & DAM & L\&H M & $\mathrm{L \& H} \mathrm{S}$ \\
\hline $0.066 * * *$ & $0.056 * * *$ & $0.299 * * *$ & $0.085 * * *$ & $0.096 * *$ \\
\hline E\&L D & E\&L F & E\&L N & E\&L S & ROU \\
\hline $0.164 * * *$ & $0.223 * * *$ & $0.165^{* * *}$ & $0.198 * * *$ & $0.406 * * *$ \\
\hline $\mathrm{D \& O}$ & CLA & & & \\
\hline 0.000 & $0.09 *$ & & & \\
\hline
\end{tabular}

Source: Selected studies. Note: marginal effects or transformed probit coefficients, results from the probit estimation, dependent variable equals one if there are positive $R \& D$ expenditures and firm is considered an innovator (new to the firm, or new to the market). The definition of innovator differs among studies. 
Table 3 Decision to innovate - market orientation variables

\begin{tabular}{lccccc}
\hline Market Orientation & H\&S & JNZ G & JNZ S & ROU & E\&L D \\
\hline National & $0.169 * * *$ & $1.215 * * *$ & $0.154 * * *$ & $0.032 * * *$ & \\
and EU & $0.142 * * *$ & $0.667 * *$ & -0.054 & $0.625 * * *$ & 0.174 \\
and World & $0.219 * * *$ & $0.739 * * *$ & $0.937 * * *$ & $0.333 * * *$ & $0.274 * *$ \\
\hline
\end{tabular}

\begin{tabular}{lccccc}
\hline Market Orientation & VOK & HALL & E\&L F & E\&L N & E\&L S \\
National & & 0.012 & & & \\
and EU & $0.16 * * *$ & $0.339 * * *$ & $0.144 * * *$ & $0.299 * * *$ & $0.307 * * *$ \\
and World & $0.51 * * *$ & $0.391 * * *$ & $0.789 * * *$ & $0.503 * * *$ & $0.585 * * *$ \\
\hline
\end{tabular}

International competition, foreign market orientation

\begin{tabular}{ccccccc}
\hline GRI F & GRI G & GRI S & GRI U & HAL & M\&V I & M\&V II \\
$0.138^{* * *}$ & $0.117 * * *$ & $0.073^{* * *}$ & $0.135^{* * *}$ & $0.036^{* * *}$ & $0.061^{* * *}$ & $0.209 * * *$ \\
\hline POL M & POL S & CAS & FAS G & FAS I & FAS S & \\
F: $0.463^{* * *}$ & F: $0.512^{* * *}$ & P: $0.289 * * *$ & $0.155^{* * *}$ & $0.066^{* * *}$ & $0.136^{* * *}$ & \\
\hline
\end{tabular}

Source: Selected studies. Note: marginal effects, results from the probit estimation, dependent variable equals one if there are positive $R \& D$ expenditures and firm is considered an innovator. The full definition of innovator may differ among studies.

Table 4 Innovation investment - Size of the firm (log of employees)

\begin{tabular}{cccccc}
\hline CDM & L\&H S & L\&H M & CAS & JNZ G & JNZ S \\
-0.029 & $-0.367 * * *$ & $-0.288^{* * *}$ & $-0.471^{* * *}$ & $-0.385^{* * *}$ & -0.067 \\
\hline ROU & E\&L D & E\&L F & E\&L N & E\&L S & DAM \\
$-0.698^{* * *}$ & 0.057 & $-0.413^{* * *}$ & $-0.318^{* *}$ & 0.009 & $1.829 * * *$ \\
\hline CLA & & & & & \\
$-0.26 * * *$ & & & & & \\
\hline
\end{tabular}

\begin{tabular}{ccccc}
\hline \multicolumn{5}{c}{ Size dummies } \\
\hline Firm's size & $50-99$ & $100-249$ & $250-999$ & $1000+$ \\
\hline VOK & $-0.58 * * *$ & $-0.61 * * *$ & $0.97 * * *$ & $-1.04 * * *$
\end{tabular}

\begin{tabular}{ccc}
\hline Firm's size & $21-50$ & $51-250$ \\
\hline HALL & $-0.271^{* *}$ & $-0.271^{*}$
\end{tabular}

Source: Selected studies. Note: Results from ML estimation. Definition of $R \& D$ expenditures may differ. Dependent variable: $\log$ of $R \& D$ expenditures per employee 
Table 5 Innovation input - Market orientation

\begin{tabular}{ccccccc}
\hline $\begin{array}{c}\text { Market } \\
\text { orientation }\end{array}$ & H\&S & E\&L D & E\&L F & E\&L N & E\&L S & HALL \\
\hline National & $0.814 * * *$ & & & & & 0.138 \\
and EU & $0.259 * * *$ & 0.239 & -0.131 & -0.17 & 0.336 & $0.511 * * *$ \\
and World & $0.301 * * *$ & 0.48 & -0.232 & 0.028 & $0.730 * *$ & $0.570 * * *$ \\
\hline
\end{tabular}

International competition, foreign market orientation

\begin{tabular}{ccccccc}
\hline GRI G & GRI S & GRI U & M\&V I & M\&V II & GRI F & HAL \\
0.119 & $0.091 *$ & 0.09 & $0.14 * *$ & $0.573 * * *$ & $0.189 * * *$ & $1.407 * * *$ \\
\hline POL M & POL S & CAS & RAF G & RAF I & RAF S & \\
$0.574 * * *$ & $0.974 * * *$ & $0.132 * * *$ & -0.276 & 0.249 & $0.525 * * *$ & \\
\hline
\end{tabular}

\section{Cooperation}

\begin{tabular}{cccccc}
\hline GRI F & GRI G & GRI S & GRI U & POL M & POL S \\
$0.186^{* * *}$ & $0.202^{* *}$ & $0.117 *$ & $0.174 * *$ & $0.432 * * *$ & $0.247 * * *$ \\
\hline RAF F & RAF E & RAF S & & & \\
$0.428 * * *$ & 0.106 & $0.551 * * *$ & & & \\
\hline
\end{tabular}

Source: Selected studies. Note: Results from ML estimation. Definition of $R \& D$ expenditures may differ. Dependent variable: $\log$ of $R \& D$ expenditures per employee

Table 6 Innovation input equation, public subsidies

\begin{tabular}{llllllll}
\hline Funding & GRI F & GRI G & GRI F & GRI F & POL M & POL S & H\&S \\
\hline Local & 0.035 & 0.223 & -0.054 & -0.074 & 0.049 & 0.132 & $-0.356^{* * *}$ \\
National & $-0.126^{* * *}$ & $-0.233^{* *}$ & $0.203^{* * *}$ & 0.045 & $0.424^{* * *}$ & $0.685^{* * *}$ & $0.863^{* * *}$ \\
EU & $0.288^{* * *}$ & -0.119 & 0.102 & 0.121 & $0.597^{* * *}$ & $0.533^{* * *}$ & $0.821^{* * *}$ \\
\hline
\end{tabular}

\begin{tabular}{lllll}
\hline Funding & VOK & RAF G & RAF I & RAF S \\
\hline Local & $0.59^{* * *}$ & $0.568^{* *}$ & 0.090 & $0.380^{* * *}$ \\
National & $0.52^{* * *}$ & 0.346 & 0.218 & $0.750^{* * *}$ \\
EU & $0.29^{* * *}$ & 0.192 & 0.049 & $0.162^{*}$ \\
\hline
\end{tabular}

Local, national, EU or EU framework programme

\begin{tabular}{ccccccc}
\hline M\&V I & M\&V II & JNZ G & JNZ S & ROU & E\&L D & HALL \\
$1.122 * * *$ & $1.417 * * *$ & 0.063 & 0.071 & $0.965^{* * *}$ & $0.396^{* * *}$ & $0.389 * * *$ \\
\hline E\&L F & E\&L N & E\&L S & RAF F & RAF E & RAF S & \\
$0.622 * * *$ & $0.448^{* * * *}$ & $0.425^{* * *}$ & $0.398^{* * *}$ & $0.507 * * *$ & 0.214 & \\
\hline
\end{tabular}

Source: Selected studies. Note: Results from ML estimation. Definition of $R \& D$ expenditures may differ. Dependent variable: log of $R \& D$ expenditures per employee. $H \& S$ dependent variable, total $R \& D$ expenditures 
Table 7 Innovation output - firm size (log of employees)

\begin{tabular}{ccccccc}
\hline Author & CDM & H\&S & L\&H S & L\&H M & CAS & JNZ G \\
\hline Firm size & -0.002 & $-0.416^{* * *}$ & $0.140^{*}$ & 0.024 & -0.063 & $-0.140^{* *}$ \\
\hline Author & JNZ S & ROU & E\&L D & E\&L F & E\&L N & E\&L S \\
\hline Firm size & -0.105 & -0.092 & -0.034 & -0.153 & 0.027 & -0.093 \\
\hline Author & D\&O & CLA prod. & CLA proc. & & & \\
\hline Firm size & $-0.194 * * *$ & $0.27 *$ & $0.02^{*}$ & & & \\
\hline
\end{tabular}

\section{Size dummies}

\begin{tabular}{ccccc}
\hline Firm's size & $50-99$ & $100-249$ & $250-999$ & $1000+$ \\
\hline VOK & $0.74 * * *$ & $0.79 * * *$ & $0.55 *$ & $0.68 * *$ \\
\hline
\end{tabular}

Source: Selected studies. Note: Results from System 1 estimation. Definition of sales from innovated goods and services may differ. Dependent variable: log of sales from innovated goods and services per employee. 
Table 8 Innovation output - firm size categories

\begin{tabular}{|c|c|c|c|c|}
\hline Process & 50-99: & 100-249: & 250-999: & 1000+: \\
\hline GRI F & 0.028 & $0.063 * *$ & $0.084 * * *$ & $0.131 * * *$ \\
\hline GRI G & 0.062 & $0.183 * * *$ & $0.225 * * *$ & $0.238 * * *$ \\
\hline GRI S & 0.015 & -0.001 & $0.101 * * *$ & $0.225 * * *$ \\
\hline GRI U & 0.011 & $0.070 * *$ & $0.146 * * *$ & 0.06 \\
\hline HAL & $0.047 * * *$ & $-0.095 * * *$ & $0.206 * * *$ & $0.145^{* * *} *$ \\
\hline Product & 50-99: & 100-249: & 250-999: & 1000+: \\
\hline GRI F & $0.093 * * *$ & 0.009 & $0.087 * * *$ & 0.05 \\
\hline GRI G & 0.076 & 0.037 & $0.147 * * *$ & 0.097 \\
\hline GRI S & $-0.044^{*}$ & $0.070 * * *$ & $0.097 * * *$ & $0.259 * * *$ \\
\hline GRI U & 0.021 & -0.004 & 0.013 & 0.049 \\
\hline HAL & 0.00 & $-0.051 * * *$ & $0.125 * * *$ & $0.135 * * *$ \\
\hline Product & $50-99$ & $100-249$ & $250-499$ & $500+$ \\
\hline RAF F & $0.106 * * *$ & $0.061 * *$ & $0.201 * * *$ & $0.234 * * *$ \\
\hline RAF E & 0.018 & 0.023 & -0.015 & $0.100 * * *$ \\
\hline RAF S & 0.030 & 0.004 & $0.097 * * *$ & $0.127 * * *$ \\
\hline Product & $21-50$ & $51-250$ & & \\
\hline HALL & $0.310 * * *$ & $0.504 * * *$ & & \\
\hline Process & $21-50$ & $51-250$ & & \\
\hline HALL & $0.255^{* * *}$ & $0.446 * * *$ & & \\
\hline Product & $50-249$ & $250+$ & & \\
\hline FAS G & 0.041 & $0.141^{*}$ & & \\
\hline FAS I & $0.034 * *$ & $0.088 * * *$ & & \\
\hline FAS S & $0.056 * * *$ & $0.173 * * *$ & & \\
\hline Process & $50-249$ & $250+$ & & \\
\hline FAS G & 0.093 & 0.046 & & \\
\hline FAS I & $0.059 * *$ & $0.125 * *$ & & \\
\hline FAS S & 0.039 & $0.219 * * *$ & & \\
\hline
\end{tabular}

Source: Selected studies. Note: Results from System 2 estimation. Dependent variables: A firm introduced product and/or process innovation over the last 3 years. 
Table 9 Innovation output - Cooperation

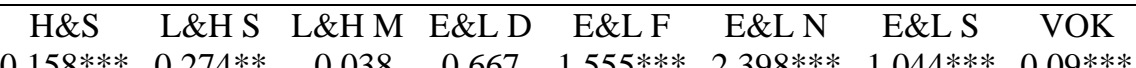

Source: Selected studies. Note: Results from System 1 estimation. Definition of sales from innovated goods and services may differ. Dependent variable: log of sales from innovated goods and services per employee.

Table 10 Innovation output - Public funding

\begin{tabular}{cccccc}
\hline M\&V I & M\&V II & M\&V & M\&V & \multirow{2}{*}{ JNZ G } & JNZ S \\
Process & Process & I Product & II Product & & \\
0.113 & 0.16 & -0.07 & $0.390^{* * *}$ & -0.016 & $-0.483^{* *}$ \\
\hline ROU & E\&L D & E\&L F & E\&L N & E\&L S & \\
-0.132 & -0.222 & $-0.396^{*}$ & $-0.668^{* * *}$ & $0.545^{* * *}$ & \\
\hline
\end{tabular}

Source: Selected studies. Note: Results from System 1 and System 2 estimation. Funding variable: A firm got a public support in an innovation programme (0/1).

Table 11 Innovation output - R\&D expenditures per employee (log)

\begin{tabular}{|c|c|c|c|c|c|c|}
\hline CDM & $\begin{array}{l}\text { GRI F } \\
\text { Proc }\end{array}$ & $\begin{array}{l}\text { GRI G } \\
\text { Proc }\end{array}$ & $\begin{array}{l}\text { GRI S } \\
\text { Proc }\end{array}$ & $\begin{array}{l}\text { GRI U } \\
\text { Proc }\end{array}$ & $\begin{array}{l}\text { M\&V I } \\
\text { Proc }\end{array}$ & $\begin{array}{l}\text { M\&V II } \\
\text { Proc }\end{array}$ \\
\hline $0.304 * * *$ & $0.440 * * *$ & $0.273 * * *$ & $0.296 * * *$ & $0.273 * * *$ & $0.172 * * *$ & $0.148 * * *$ \\
\hline POL M & POL S & GRI F & GRI G & GRI S & GRI U & M\&V I \\
\hline Proc & Proc & Prod & Prod & Prod & Prod & Prod \\
\hline $1.044 * *$ & -0.831 & $0.303 * * *$ & $0.260 * * *$ & $0.281 * * *$ & $0.161 * * *$ & $0.107 * * *$ \\
\hline JNZ S & $\mathrm{ROU}$ & E\&L D & E\&L F & $\mathrm{E} \& \mathrm{~L} \mathrm{~N}$ & E\&L S & DAM \\
\hline $0.610 * * *$ & $0.267 * * *$ & 0.276 & 0.225 & $0.677 * * *$ & $0.331 * * *$ & $0.168 * * *$ \\
\hline $\begin{array}{c}\text { M\&V II } \\
\text { Prod }\end{array}$ & $\begin{array}{l}\text { POL M } \\
\text { Prod }\end{array}$ & $\begin{array}{c}\text { POL S } \\
\text { Prod }\end{array}$ & L\&H S & $\mathrm{L} \& \mathrm{H} M$ & CAS & JNZ G \\
\hline $0.113 * * *$ & 0.618 & -0.672 & $0.614 * * *$ & $0.562 * * *$ & $0.429 *$ & $0.495 * * *$ \\
\hline VOK & $\begin{array}{l}\text { RAF F } \\
\text { Prod }\end{array}$ & $\begin{array}{l}\text { RAFE } \\
\text { Prod }\end{array}$ & $\begin{array}{l}\text { RAF S } \\
\text { Prod }\end{array}$ & $\mathrm{D} \& \mathrm{O}$ & $\begin{array}{l}\text { HALL } \\
\text { Prod. }\end{array}$ & Hall proc. \\
\hline $0.05 * * *$ & $0.745 * * *$ & $0.387 * * *$ & $0.407 * * *$ & 0.026 & $0.686 * * *$ & $0.483 * * *$ \\
\hline FAS G & FAS I & FAS S & FAS G & FAS I & FAS S & CLA \\
\hline Prod. & Prod. & Prod. & Proc. & Proc. & Proc. & Proc. \\
\hline 0.116 & 0.010 & $0.042 * * *$ & $0.288 * * *$ & 0.066 & $0.054 * *$ & 0.00 \\
\hline $\begin{array}{c}\text { CLA } \\
\text { Prod. } \\
0.61 \\
\end{array}$ & & & & & & \\
\hline
\end{tabular}

Source: Selected studies. Note: Results from System 1 and System 2 estimation. Dependent variable: $\log$ of $R \& D$ expenditures per employee. Dependent variable in system 1: log of sales from innovated goods and services per employee. Dependent variable in system 2: product and/or process innovation $(0 / 1)$ 
Table 12 Innovation output - Sales per employee $(\log )$

\begin{tabular}{ccccccc}
\hline JNZ G & JNZ S & ROU & E\&L D & E\&L F & E\&L N & E\&L S \\
$1.063 * * *$ & 0.595 & 0.565 & $0.436 * *$ & 0.328 & -0.363 & $0.529 *$ \\
\hline VOK & D\&O & & & & & \\
$1.22 * * *$ & turnover & & & & & \\
\hline
\end{tabular}

Source: Selected studies. Note: Results from System 1 estimation. Dependent variable: log of sales from innovated goods and services per employee.

Table 13 Production equation, log of fixed assets / capital per employee

\begin{tabular}{cccccc}
\hline CDM & GRI F & GRI G & GRI S & GRI U & M\&V I \\
$0.198^{* * *}$ & $0.130^{* * *}$ & $0.109 * * *$ & $0.061^{* * *}$ & $0.059 * * *$ & $0.34 * * *$ \\
\hline M\&V II & POL M & POL S & L\&H S & L\&H M & JNZ G \\
$0.268^{* * *}$ & $0.207 * * *$ & $0.261^{* * *}$ & $0.052^{* * *}$ & $0.140^{* * *}$ & $0.134 * * *$ \\
\hline JNZ S & ROU & E\&L D & E\&L F & E\&L N & E\&L S \\
0.04 & $0.153^{* * *}$ & $0.360^{* * *}$ & $0.269 * * *$ & $0.208^{* * *}$ & $0.183 * * *$ \\
\hline VOK & & & & & \\
$0.08 * * *$ & & & & & \\
\hline
\end{tabular}

Source: Selected studies. Note: Dependent variable: log of sales per employee or turnover per employee.

Table 14 Production equation, innovation output effect

\begin{tabular}{lcccc}
\hline & GRI F & GRI G & GRI S & GRI U \\
\hline Product I. & $0.060 * * *$ & -0.053 & $0.178^{* * *}$ & $0.055^{* * *}$ \\
Process I. & $0.069 *$ & 0.022 & -0.038 & 0.029 \\
\hline & RAF F & RAF E & RAF S & HALL \\
Product I. & $0.075 * *$ & $0.156 * * *$ & $0.101 *$ & $0.597 * * *$ \\
Process I. & & & & 0.193 \\
\hline & M\&V I & M\&V II & POL M & POL S \\
\hline Product I. & $0.168 * *$ & 0.027 & -0.079 & $0.917 * * *$ \\
Process I. & -0.027 & $0.182 * * *$ & 0.095 & $7.252 * * *$ \\
\hline Product I. & FAS G & FAS I & FAS S & CLA \\
Process I. & $2.59 * * *$ & $1.52 * * *$ & $-2.78 * * *$ & $0.17 * * *$ \\
\hline
\end{tabular}

Sales of innovated goods and services per employee

\begin{tabular}{ccccccc}
\hline L\&H S & L\&H M & CAS & JNZ G & JNZ S & ROU & VOK \\
$0.093 * *$ & $0.012^{* * *}$ & $0.476 * * *$ & $0.268^{* * *}$ & $0.29 * * *$ & $0.142 * * *$ & $0.24 * * *$ \\
\hline E\&L D & E\&L F & E\&L N & E\&L S & CDM & H\&S & D\&O \\
0.404 & $0.202 * *$ & 0.064 & $0.221 * *$ & $0.065 * * *$ & $1.638 * * *$ & $0.609 * * *$ \\
\hline
\end{tabular}

Source: Selected studies. Note: Dependent variable: log of sales per employee or turnover per employee. 
Table 15 Production equation - firm size (log of employees)

\begin{tabular}{cccccc}
\hline CDM & M\&V I & M\&V II & POL M & POL S & D\&O \\
0.007 & $-0.059 * * *$ & $-0.058^{* * *}$ & $0.038^{* *}$ & $-0.131 * * *$ & $0.165 *$ \\
\hline CAS & JNZ G & JNZ S & ROU & E\&L D & CLA \\
$-0.447 * * *$ & $0.146^{* * *}$ & $0.06 *$ & $-0.172 * * *$ & $0.352 * * *$ & 0.04 \\
\hline E\&L F & E\&L N & DAM & E\&L S & L\&H S & L\&H M \\
-0.009 & $0.043^{*}$ & $-0.219 * * *$ & 0.006 & 0.005 & -0.007
\end{tabular}

Source: Selected studies. Note: Dependent variable: log of sales per employee or turnover per employee.

Table 16 Production equation, firm size as a dummy variable

\begin{tabular}{ccccc}
\hline Size & $50-99:$ & $100-249:$ & $250-999:$ & $1000+:$ \\
\hline GRI F & $-0.091 * * *$ & $-0.059^{* *}$ & 0.024 & $0.183^{* * *}$ \\
GRI G & $0.083^{*}$ & $0.250^{* * *}$ & $0.281 * * *$ & $0.455^{* * *}$ \\
GRI N & $0.108^{* *}$ & $0.152^{* * *}$ & $0.350^{* * *}$ & $0.510^{* * *}$ \\
GRI S & $0.070^{* *}$ & $0.153^{* * *}$ & $0.274 * * *$ & $0.268^{* * *}$ \\
HAL & $-0.085 * *$ & $-0.072^{*}$ & $-0.106 * *$ & $1.199 * * *$ \\
VOK & $-0.35^{* * *}$ & $-0.44 * * *$ & $-0.47 * * *$ & $-0.54 * * *$ \\
\hline
\end{tabular}

\begin{tabular}{ccccc}
\hline Size & $50-99:$ & $100-249:$ & $250-499:$ & $500+:$ \\
\hline RAF F & $-0.095^{* * *}$ & $-0.114^{* * *}$ & $-0.057 *$ & $0.050^{*}$ \\
RAF E & $0.112^{* * *}$ & $0.089^{* * *}$ & $0.106^{* * *}$ & $0.272^{* * *}$ \\
RAFS & 0.003 & 0.033 & 0.059 & 0.097 \\
\hline
\end{tabular}

\begin{tabular}{ccc}
\hline Size & $21-50:$ & $51-250:$ \\
\hline HALL & $-0.136^{* * *}$ & $-0.243 * * *$ \\
\hline & & \\
\hline Size & $50-249$ & $250+$ \\
\hline FAS G & $1.598^{* * *}$ & $3.174 * * *$ \\
FAS I & $1.892^{* * *}$ & $3.390 * * *$ \\
FAS S & $1.868^{* * *}$ & $3.427 * * *$ \\
\hline
\end{tabular}

Source: Selected studies. Note: Dependent variable: log of sales per employee or turnover per employee. 